\title{
EFFECTIVENESS OF HEALTH PROMOTION THROUGH THE AUDIO VISUAL MEDIA RISK OF TRANSMISSION OF HIV / AIDS ON THE MOTIVATION OF YOUTH IN SMAN 10 BANJARMASIN
}

\author{
Ahmad Syahlani ${ }^{1 *}$ \\ ${ }^{1}$ Saint Paul University Philipines \\ Ahmad_syahlani@gmail.com \\ Tanwiriah $^{2}$ \\ ${ }^{2}$ Psychiatric Hospital Sambang Lihum Banjarmasin \\ tanwiriyah@gmail.com \\ Abdul Latif ${ }^{3}$ \\ ${ }^{3}$ Sekolah Tinggi Ilmu Kesehatan Sari Mulia Banjarmasin \\ *abdul_latif@gmail.com
}

\begin{abstract}
Objective: To analyze the influence of Health Promotion through Audio Visual Media about the risk of HIV/AIDS transmission to Motivate Of Adolescents in SMAN 10 Banjarmasin

Method: One group pretest-posttest research was conducted on May 20, 2017, at SMAN 10 Banjarmasin. This research was conducted on 66 students of class XI with cluster sampling technique was taken representatives of 11 people from each class XI IPA IPS. Data were collected using questionnaire, then analyzed using Wilcoxon test.

Result: The results showed that the use of audio-visual media before the health promotion 56 people $(84.8 \%)$ negative and after health promotion 60 people $(90.9 \%)$ positive with $p$-value 0,000 . Before to promotion 53 people $(80.3 \%)$ had low motivation and after health promotion, there were 55 people $(83,3 \%)$ have high motivation with $\mathrm{P}$-value 0,000 .

Conclusion: There is the influence of health promotion through audiovisual media about HIV/AIDS transmission risk to adolescent motivation.
\end{abstract}

Keywords: Adolescent, Audio Visual Media, HIV / AIDS, Motivation.

\section{INTRODUCTION}

Human Immunodeficiency Virus (HIV)

and Acquired Immunodeficiency Syndrome

(AIDS) are health problems worldwide. The

World Health Organization (WHO) states that
HIV / AIDS is a global threat and has adverse impacts on all sectors.

A global HIV epidemic report by 2015 as many as 2.1 million people has been infected with HIV. Based on the results of World Health Organization (WHO) data in 2013 as 
many as 230,000 teenagers died and nearly 75 million people have been infected with HIV. It is therefore estimated that $0.8 \%$ of the $15-$ 29 age group worldwide living with HIV. The number of HIV cases in Indonesia in 2014 is 22,869 cases and AIDS cases are 1,876 cases. The highest HIV infection at the productive age of 25-49 years old is $71,8 \%$ followed by age $20-24$ year equal to $15,7 \%$ in 2014 [1]. While in South Kalimantan province, the spread of HIV / AIDS cases in September 2015 has reached 1,194 cases, whereas in 2014 there were 1,014 cases. While in terms of age group mostly in the age range 15-29 years [2].

Infection in adolescents can threaten the life of adolescents, but it can also transmit to the partner. Because of a large number of HIV-infected adolescents, HIV / AIDS prevention efforts are needed. But to change the behavior required motivation because the motivation is the interaction between behavior and the environment so as to increase, decrease and maintain one's behavior [3].

Adolescents are among the factors at risk of contracting HIV / AIDS due to misbehaving adolescents such as sharing needles and sexual behavior (Kumalasari, 2013). One of Anderon's theories in a Behavioral model of the families use of health services (1977) states that behavior can be determined or formed from three factors such as 1). Predisposing factors, 2) Enabling Factors, 3). Reinforcing Factor. One of the factors mentioned that the information media included in Enabling Factors where the information media used to convey messages or health information included in the media information is audiovisual media [3].

The audio-visual media contributes enormously to the changing behavior of people. This method provides a stimulus to hearing and sight so that the results obtained more leverage [4].

The government program in dealing with HIV / AIDS nationally by developing the National Strategy and Action Plan (SRAN) 2010-2014, its target of achievement over the next 5 years is aimed at preventing and reducing the risk of HIV transmission, improving the quality of life of PLWHA, and reducing the social and economic impact due 
to HIV / AIDS in individuals, families and communities, in order for individuals and communities to be productive and beneficial to development. This strategy and action plan in 2014 is that $80 \%$ of the key populations are affordable by effective programs and $60 \%$ of the key populations are safe [5].

Efforts that have been made by the government in addressing HIV / AIDS include promotive, preventive, curative and rehabilitative efforts, by providing services that support the prevention of HIV / AIDS epidemics throughout districts/cities that have HIV / AIDS cases. These services include HIV counseling and voluntary counseling, care, support and treatment (PDP) services, mother-to-child transmission prevention (PPIA) services, methadone maintenance therapy program (PTRM), sterile syringe service (LASS), prison services, and prisons (Rutan), which carries out HIV / AIDS control and sexually transmitted infections (STIs) as health promotion activities such as promotion of condom use for high risk groups and health promotion on HIV / AIDS to adolescents and the general public [5].
Based on a preliminary study by researchers on November 28, 2016, through interviews with teachers of BP / BK SMA 10 Banjarmasin, during the last 3 years, there has been no health education about the risk of HIV / AIDS transmission in schools and there are 78 violations for one year. The results of interviews with 10 students and students of class XI said that they are less aware of HIV / AIDS that they know only HIV / AIDS is a contagious disease.

From the background above, the researchers are interested to examine the effectiveness of health promotion through audiovisual media about the risk of HIV / AIDS transmission to the motivation of adolescents in SMA 10 Banjarmasin.

\section{METHOD}

This research uses the QuasiExperimental method with One Group pretest-posttest research design. The sample in this study are respondents who come from class XI IPA and IPS consisting of 6 classes in SMAN 10 Banjarmasin amounted to 66 people with Cluster sampling technique that is 
grouping the sample by region or population

location. For the sample, proportional fraction sampling method is used per cluster, so that each class there are 11 students who become subsamples. Data retrieval using questionnaire that has been declared valid \& reliably and using Wilcoxon test.

\section{RESULTS}

\section{Univariate Analysis}

\section{Respondents' Characteristics}

In this study the characteristics of respondents consisted of age and sex presented in the table as follows:

Table 1. Characteristics Based on Age At SMAN 10 Banjarmasin

\begin{tabular}{ccc}
\hline Ages & Frequency & Percentage \\
\hline 16 years & 17 & 25,8 \\
17 years & 37 & 56,1 \\
18 years & 12 & 12,2 \\
\hline Tolta & 66 & 100 \\
\hline
\end{tabular}

Source: Primary Data, 2017

Respondents who participated in health promotion through audio-visual media about the risk of HIV / AIDS transmission at most age 17 years were 37 people $(56,1 \%)$.

Table 2. Characteristics by Sex At SMAN 10 Banjarmasin

\begin{tabular}{ccc}
\hline Genders & Frequency & Percentage \\
\hline Males & 31 & 47,0 \\
Females & 35 & 53,0 \\
\hline Total & 66 & 100 \\
\hline
\end{tabular}

Source: Primary Data, 2017
The gender of respondents who participated in health promotion through audiovisual media about the risk of HIV / AIDS transmission were 35 women (53\%) and 31 men $(47 \%)$

\section{Promotional Materials on Health}

Table 3. Distribution of Frequency of Health Promotion Material Regarding the Risk of Transmission

\begin{tabular}{cccccc}
\hline Variable & $\begin{array}{c}\text { Std. } \\
\text { Deviatio } \\
\mathrm{n}\end{array}$ & Mean & Median & $\begin{array}{c}\text { Min } \\
\text { value }\end{array}$ & $\begin{array}{c}\text { Max } \\
\text { value }\end{array}$ \\
\hline $\begin{array}{c}\text { Pre Test } \\
\text { Post }\end{array}$ & 1.73 & 12.39 & 12.00 & 10.00 & 18.00 \\
Test & 3,23 & 18.51 & 18.00 & 12.00 & 24.00 \\
\hline Source: Primary
\end{tabular}

Source: Primary Data, 2017

Table 3 indicates an increase in mean value from 12.39 at pre-test to 18.51 at post-test with a difference of the value of 6.12 . Standard deviation at pre-test is 1.73 and at post-test is 3.23 with a difference of 1.5 .

1) Pre-Test Promotional Material About the Risk of HIV/AIDS Transmission is presented in table 4 below.

Table 4

\begin{tabular}{ccc}
\hline Category & Frequency & Percentage \\
\hline Negative & 59 & 89.4 \\
Positive & 7 & 10.6 \\
\hline Total & 66 & 100
\end{tabular}

Source: Primary Data, 2017

Table 4 shows that negative health promotion materials were 59 people $(89.4 \%)$ and positive health promotion materials were 7 (10.6\%). 
2) Post-Test Promotional Material About the Risk of HIV/AIDS Transmission is presented in table 5 below

Table 5.

\begin{tabular}{ccc}
\hline Category & Frequency & Percentage \\
\hline Negative & 7 & 10.6 \\
Positive & 59 & 89.4 \\
\hline Total & 66 & 100 \\
\hline
\end{tabular}

Source: Primary Data, 2017

Table 5 shows that respondents considered negative health promotion material as many as 7 people $(10.6 \%)$ and respondents considered positive health promotion material as many as 59 people $(89.4 \%)$ after health promotion.

\section{Media Health Promotion}

Table 6. Distribusi Frekuensi Media Promosi Kesehatan di SMAN 10 Banjarmasin

\begin{tabular}{cccccc}
\hline Variabel & $\begin{array}{c}\text { Std. } \\
\text { Deviatio } \\
\mathrm{n}\end{array}$ & Mean & Median & $\begin{array}{c}\text { Min. } \\
\text { value }\end{array}$ & $\begin{array}{c}\text { Max } \\
\text { value }\end{array}$ \\
\hline $\begin{array}{c}\text { Pre Test } \\
\text { Post } \\
\text { Test }\end{array}$ & 2.00 & 12.07 & 12.00 & 8.00 & 16.00 \\
\hline
\end{tabular}

Source: Primary Data, 2017

Table 6 shows an average increase of 12.07 during pre-test to 18.10 at post-test with a difference of 6.03. Standard deviation when pretest 2.00 and posttest 2.70 with a difference of 0.7 .

Pre-Test of Health Promotional Media is presented in table 7

\begin{tabular}{ccc}
\hline Category & Frequency & Percentage \\
\hline Negative & 56 & 84.8 \\
Positive & 10 & 15.2 \\
\hline Total & 66 & 100 \\
\hline Source: Primary Data, 2017 &
\end{tabular}

Source: Primary Data, 2017
Table 7 shows that health promotion media used negatively as many as 56 people $(84.8 \%)$ and health promotion media used positively as many as 10 people (15.2\%).

Post Test of Health Promotional Media is presented in table 8 below

Table 8

\begin{tabular}{ccc}
\hline Category & Frequency & Percentage \\
\hline Negative & 6 & 9.1 \\
Positive & 60 & 90.9 \\
\hline Total & 66 & 100 \\
\hline
\end{tabular}

Source: Primary Data, 2017

Table 8 shows that health promotion media used negatively as many as 6 people $(9.1 \%)$ and health promotion media used positively as many as 60 people $(90.9 \%)$ after health promotion.

\section{Teenagers' Motivation}

Table 9. Frequency of Distribution of Teenagers' Motivation Regarding the Risk of HIV/AIDS Transmission

\begin{tabular}{cccccc}
\hline Variable & $\begin{array}{c}\text { Std. } \\
\text { Deviati } \\
\text { on }\end{array}$ & Mean & Median & $\begin{array}{c}\text { Min. } \\
\text { value }\end{array}$ & $\begin{array}{c}\text { Mx } \\
\text { Valu } \\
\text { e }\end{array}$ \\
\hline $\begin{array}{c}\text { Pre Test } \\
\text { Post } \\
\text { Test }\end{array}$ & 4.25 & 22.25 & 21.00 & 16.00 & 35.0 \\
\hline \multicolumn{2}{l}{ Source: Primary Data, 2017 } & & & & \\
\hline
\end{tabular}

Table 9 indicates an increase in the mean value of 22.25 during pre-test to 28.28 at post-test with a difference of 6.03. Standard deviation at pre-test 4.25 and at posttest 4.64 with difference of 0.39 
1) Pre-Test of the Teenagers' Motivation Regarding the Risk of HIV/AIDS is shown in table 10 below.

Table 10.

\begin{tabular}{ccc}
\hline Category & Frequency & Percentage \\
\hline Low & 53 & 80.3 \\
High & 13 & 19.7 \\
\hline Total & 66 & 100 \\
\hline
\end{tabular}

Source: Primary Data, 2017

Table 10 shows that respondents have low motivation as many as 53 people $(80.3 \%)$ and respondents have high motivation as many as 13 people $(19.7 \%)$.

2) Post-Test of Teenagers' Motivation about the Risk of HIV/AIDS transmission is shown in table 11 below:

Table 11.

\begin{tabular}{ccc}
\hline Category & Frequency & Percentage \\
\hline Low & 11 & 16.7 \\
High & 55 & 83.3 \\
\hline Total & 66 & 100 \\
\hline
\end{tabular}

Source: Primary Data, 2017

Table 11 shows that respondents have low motivation as many as 11 people $(16.7 \%)$ and respondents have high motivation as many as 55 people $(83.3 \%)$ after health promotion.

\section{BIVARIATE ANALYSIS}

\section{Health Promotional Material}

Table 12. Result of Analysis of Health Promotion Material Influence Regarding the risk of HIV / AIDS Transmission

\begin{tabular}{cccc}
\hline Category & $\mathrm{N}$ & Mean Rank & $p$-value \\
\hline Negative ranks & 1 & 10,50 & \\
Positive Ranks & 60 & 31,34 & 0,000 \\
Ties & 5 & & \\
\hline
\end{tabular}

Source: Primary Data, 2017

Table 12 shows that the negative ranks value is 1 with the mean rank value of 10.50 , while the positive ranks value is 60 with the mean rank value of 31.34 . The results obtained $\mathrm{p}$ value 0,000 which means that health promotion materials about the risk of HIV / AIDS transmission have a significant influence.

\section{Health Promotional Media}

Table 13. Results of Analysis of Health Promotion Through Audio Visual

\begin{tabular}{cccc}
\hline Category & $\mathrm{N}$ & Mean Rank & p-value \\
\hline Negative ranks & 2 & 3,50 & \\
Positive Ranks & 62 & 33,44 & 0,000 \\
Ties & 2 & & \\
\hline Source: Primary Data & 2017 & &
\end{tabular}

Source: Primary Data, 2017

Table 13 shows the negative ranks as much as 2 people with the mean value 3.50 , while the positive ranks as much as 62 with the mean rank 33.44. The results obtained p-value 0,000 which means that the promotion of health through audiovisual has a significant influence.

\section{Teenagers' Motivation}

Table 14. Results of Analysis of Health Promotion Through Audio Visual Concerning Risk of HIV / AIDS Transfers Against Youth Motivation

\begin{tabular}{cccc}
\hline Category & $\mathrm{N}$ & Mean Rank & p-value \\
\hline Negative ranks & 9 & 19,11 & \\
Positive Ranks & 56 & 35,23 & 0,000 \\
Ties & 1 & & \\
\hline
\end{tabular}

Source: Primary Data, 2017 
Table 14 shows that the negative ranks of 2 people with the mean value of 19.11, while the positive ranks value 56 with the mean rank value 35.23 . The results obtained p-value 0,000 which means that health promotion through audio-visual about the risk of HIV / AIDS transmission has a significant influence on the motivation of adolescents in SMAN 10 Banjarmasin.

\section{DISCUSSION}

\section{Health Promotional Material}

Health promotion is an educational process that can not be separated from the learning process. A person can be said to learn when in itself a change, from not knowing to know, from not being able to do something to be able to do something. In the learning process, there is mutual influence between various factors, among others, the subject of learning, faculty or facilitator learning, the methods used and the materials or materials studied.

The material used in this study is easy to understand students. In addition, the material presented contains several images that help students understand the material provided by the researcher. However, there are some students who still find it difficult to understand the health promotion materials provided. This is due to a lack of student concentration and an unfavorable environment.

This agrees with Prastowo theory (2013) which shows that learning materials should be oriented that students will more easily understand a concept when starting from the easy ones. In addition, the material given in the lesson should provide encouragement or motivation for students to learn [6].

\section{Health Promotional Media}

The use of audio-visual media in this study using video, powerpoint and leaflet. The purpose of using audiovisual media to facilitate students in understanding complex concepts to be more simple and easy to understand. In addition, audiovisual also aims as a tool in supporting a learning process and motivate students to be more diligent learning. The use of audio-visual media is more easily 
accepted by the student's learning messages compared with verbal messages.

This is in line with the theory of Kholid (2014) which says that the audiovisual media provide stimulus to hearing and sight so that the results obtained more leverage. These results can be achieved because the senses that transmit the most knowledge to the brain is the eye (approximately 75 to $87 \%$ ), while 13 to $25 \%$ of knowledge from the other five senses [4].

This research is also in line with research by Parman (2013) which shows that there is an influence between the acquisition of the results of the practice of worship of students who use audiovisual media compared with the acquisition of the results of worship practices that use print media [7]. In addition, this study is reinforced by research from Kumboyono (2011) who said that there are differences in health education effects using print media with audiovisual media with a significant value of 0.009 [8].

\section{Teenagers' Motivation}

Increased one's motivation through the promotion of health because of health promotion can affect a person in having knowledge and motivation. In addition, the provision of health promotion strives for students to be aware of and realize the importance of HIV / AIDS transmission risk. A person's motivation can be formed by internal and external motivation for him to make a change of motivation one of them with health promotion. However, in this study, there are still some respondents who did not experience increased motivation or who have the same level of motivation. This is because the reception of each person's information is different.

This is in line with the theory of Hamzah (2008) which says that motivation can be formed by intrinsic factors such as the desire, the existence of awards and extrinsic factors such as the existence of a conducive environment and interesting activities in learning [9].

This research is also in line with research by Darmawan (2014) which 
shows that there is the influence of health promotion to the motivation of hypertension patient about the implementation of hypertension diet [10]. In addition, this study is also reinforced by research by Sodiq (2016) which states that there is the influence of the use of audiovisual media to increase the motivation of adolescents in learning [11]. However, this study is not in line with Irfan's research (2016) which states that there is no difference in learning motivation of students who are taught without using audio-visual media and are taught using audio-visual media with a significant level of P-value 0.078 [12].

\section{REFERENCES}

[1]. Kementerian Kesehatan RI. Pusat Data \& Informasi. 2014. http://www.depkes.go.id [di akses 18 November 2016].

[2]. Dinas Kesehatan. Profil Kesehatan Kota Banjarmasin. 2015. Banjarmasin : Dinas Kesehatan Banjarmasin.

[3].Notoatmodjo, Soekidjo. Promosi Kesehatan Teori dan Aplikasi. 2010. Jakarta: Rineka Cipta.

[4]. Kholid, Akhmad. Promosi Kesehatan. 2014. Jakarta: Rajawali Pers.

[5]. Komisi Penanggulangan Aids. 2010. Info HIV \& AIDS. Jakarta.

[6]. Prastowo, Andi. 2013. Pengembangan Bahan Ajar Tematik. Yogyakarta: Diva Press.
[7]. Parman. 2013. Pengaruh Penggunaan Media Audio Visual Dan Motivasi Terhadap Hasil Praktik Ibadah Siswa Di Smp. Jurnal Tekno-Pedagogi [internet]. 3 (1) : 50-58.

[8]. Kumboyono. 2011. Perbedaan Efek Penyuluhan Kesehatan Menggunakan Media Cetak Dengan Media Audio Visual Terhadap Peningkatan Pasien Tuberkulosis. Jurnal Ilmiah Kesehatan Keperawatan. 7 (1).

[9]. Hamzah, B. 2008. Teori Motivasi dan Pengukurannya. Jakarta: Bumi Aksara.

[10]. Darmawan, Dadang. 2014. Pengaruh Promosi Kesehatan Terhadap Motivasi Pasien Hipertensi Tentang Pelaksanaan Diet Hipertensi Di Poliklinik Penyakit Dalam Rs. Rajawali Bandung. Jurnal Online Mahasiswa (JOM) Bidang Ilmu Keperawatan [internet]. 16 (2).

[11]. Shodiq. 2016. Pengaruh Penggunaan Media Audio Visual terhadap Motivasi dan Prestasi Belajar Siswa Dalam Pembelajaran Sejarah Kebudayaan Islam Kelas $V$ Madrasah Ibtidayah Negeri Malang [Tesis]. Malang: Universitas Islam Negeri Maulana Malik Ibrahim.

[12]. Irfan, Ahmad. 2016. Perbedaan Media Audio Visual dan Bukan Audio Visual Terhadap Motivasi dan Hasil Belajar IPS Siswa Kelas IV. Jurnal Keperawatan [internet]. 24 (1). 